\title{
РЕКОНСТРУКЦІЯ КАРОТИДНОГО БАСЕЙНУ В УМОВАХ РОЗВИТКУ ПІЗНІХ УСКЛАДНЕНЬ ПІСЛЯ РЕВАСКУЛЯРИЗАЦІЇ АОРТО-КЛУБОВО-СТЕГНОВОГО СЕГМЕНТА
}

\section{Реконструкція каротидного басейну в умовах розвитку пізніх ускладнень після реваскуляризації аорто-клубово-стегнового сегмента}

\section{І. К. Венгер, С. Я. Костів, А. Р. Вайда, Б. П. Сельський}

Тернопільський національний медичний університет імені І. Я. Горбачевського МОЗ України

Резюме. Серед пацієнтів з атеросклеротичною оклюзією термінального відділу аорти і магістральних артерій нижніх кінцівок частота уражень брахіоцефральних артерій сягає 40-72\%.

Мета дослідження - покращити результати лікування пацієнтів з атеросклеротичним ураженням екстракраніальних артерій в умовах розвитку віддалених ускладнень після реваскуляризації аорто-клубовостегнового сегмента.

Матеріали і методи. Серед 522 хворих, оперованих протягом 2006-2019 рр. з приводу атеросклеротичної оклюзії аорто-клубово-стегнової зони у віддаленому післяопераційному періоді, діагностовано 148 (28,35 \%) пізніх ускладнень. Серед них у 132 (89,19 \%) виявлено атеросклеротичне ураження внутрішньої сонної артерії (BCA). Характер атеросклеротичного ураження, ступінь оклюзивного процесу і стан церебральної гемодинаміки визначали за допомогою ультрасонографра «Siemens Acuson S2000», магнітно-резонансного томографра Tesla Excelart Vantage Toshiba Medical System, комп'ютерної томографрії із ангіопідсиленням на апараті Philips Brilliance 64.

Результати. У пацієнтів із атеросклеротичним ураженням екстракраніальних артерій найчастіше виявляли безсимптомне ураження у 61 (70,12 \%) спостереженні, транзиторну ішемічну атаку - в 17 (20,99 \%) осіб. Набагато рідше було діагностовано інсульт доконаний - у 2 (2,30 \%) хворих. При хірургічній корекції кровообігу по внутрішній сонній артерії виконали 43 (49,43 \%) класичних каротидних ендартеректомій (KE), 23 (26,44 \%) - ретроградних KE, 11 (12,64 \%) - еверсійних KE. У 8 спостереженнях (9,19 \%) здійснене стентування ВСА. Після КE ВСА 85 пацієнтам проведено хірургічне втручання з приводу віддалених ускладнень оперативного лікування аорто-клубово-стегнового артеріального басейну. В 78 (91,76 \%) спостереженнях повторна реконструктивна операція пізніх ускладнень здійснена одномоментно із KE BCA. Наступним етапом хірургічного лікування було оперативне втручання при різних фрормах пізніх ускладнень реконструкції аорто-стегнового
Reconstruction of the carotid basin in the conditions of development of late complications after revascularization of the aorto-femoral segment

I. K. Venher, S. Ya. Kostiv, A. R. Vaida, B. P. Selskiy

I. Horbachevsky Ternopil National Medical University e-mail: kostivsj@tdmu.edu.ua

Summary. Among patients with atherosclerotic occlusion of the terminal aorta and main arteries of the lower extremities, the frequency of the brachiocephalic arteries lesions is 40-72\%.

The aim of the study - to improve the results of treatment of patients with atherosclerotic lesions of the extracranial arteries in the development at distant complications after revascularization of the aorto-iliacfemoral segment.

Materials and Methods. Among 522 patients operated in 2006-2019 for atherosclerotic occlusion of the aorto/iliac-femoral zone in the remote postoperative period 148 (28.35\%) late complications were diagnosed. Among them, atherosclerotic lesions of the internal carotid artery (ICA) were found in 132 (89.19\%). The nature of atherosclerotic lesions, the degree of occlusive process and the state of cerebral hemodynamics were determined using an ultrasonograph "Siemens Acuson S2000, magnetic resonance imaging Tesla Excelart Vantage Toshiba Medical System, computed tomography Philips Brilliance 64.

Results. Patients with atherosclerotic lesions of the extracranial arteries showed asymptomatic course in 61 $(70.12 \%)$ cases, transient ischemic attack - in 17 (20.99\%) people. Stroke was diagnosed in 2 (2.30\%) patients. 43 (49.43\%) - classical carotid endarterectomies, $23(26.44 \%)$ - retrograde carotid endarterectomies, and 11 (12.64 \%) - eversion carotid endarterectomies were performed during surgical correction of blood flow through the internal carotid artery. In 8 observations (9.19\%) stenting of the internal carotid artery was performed. After carotid endarterectomy, 85 patients underwent surgery for long-term complications of surgical treatment of the aortofemoral arterial segment. In 78 (91.76 \%) cases, repeated reconstructive surgery of late complications was performed simultaneously with carotid endarterectomy. The next stage of surgical treatment was surgery for various forms of late complications of reconstruction of the aortofemoral arterial segment. 8 (9.41\%) thrombosis of recon- 
артеріального басейну. Діагностовано 8 (9,41 \%) тромбозів реконструйованих сегментів. Повторні хірургічні втручання у 2 спостереженнях не мали успіху й у них була проведена ампутація нижньої кінцівки.

Висновки. Виконання КЕ в поєднанні із хірургічним лікуванням віддалених ускладнень реваскуляризації атеросклеротичного ураження аорто-клубово-стегнового артеріального басейну дало можливість попередити розвиток неврологічних ускладнень і досягти в 94,1 \% хороших результатів у хірургічному лікуванні поєднаного атеросклеротичного ураження ВСА і віддалених ускладнень реконструктивних операцій атеросклеротичної оклюзії аорто-клубово-стегнової артеріальної зони.

Ключові слова: облітеруючий атеросклероз; артеріальна реконструкція; каротидна ендартеректомія; реваскуляризація.

\section{ВСТУП}

Проблема судинної патології головного мозку $є$ однією з актуальних у сучасній клінічній медицині, оскільки тісно пов'язана із значною частотою розвитку ускладнень, значним відсотком інвалідизації та смертності [1, 2]. Поширеною причиною гострих та хронічних захворювань мозку є стенотичні та оклюзивні ураження магістральних артерій голови та шиї [3]. До особливостей патології сонних артерій належить множинний характер ураження судин та інших артеріальних басейнів [4]. Серед пацієнтів із атеросклеротичною оклюзією термінального відділу аорти і магістральних артерій нижніх кінцівок частота уражень брахіоцефральних артерій сягає 40-72 \% [5]. Реконструкція черевного відділу аорти або ж аорто-стегнового сегмента у вказаної категорії хворих нерідко супроводжується високим ризиком появи неврологічних ускладнень [6]. Для попередження їх розвитку запропоновано ряд тактичних підходів у виконанні хірургічного лікування при поєднаному атеросклеротичному стенотичному процесі сонних судин та оклюзії аорто-стегнової артеріальної зони [7].

Метою дослідження було покращити результати лікування пацієнтів із атеросклеротичним ураженням екстракраніальних артерій в умовах розвитку віддалених ускладнень після реваскуляризації аорто-клубово-стегнового сегмента.

\section{МАТЕРІАЛИ I МЕТОДИ}

Серед 522 хворих, оперованих протягом 20062019 рр. з приводу атеросклеротичної оклюзії аорто-клубово-стегнової зони у віддаленому післяопераційному періоді, діагностовано 148 (28,35 \%) пізніх ускладнень. 3 них 5 (3,39 \%) перенесли інфраркт міокарда, 2 (1,35 \%) - гостре порушення мозкового кровообігу, 141 (95,27 \%) - ускладнення аорто-клубово-стегнової зони. Із пізніх ускладнень аорто-клубово-стегнової ділянки у 47 (33,33 \%) па- structed segments was diagnosed. Repeated surgeries in 2 observations were unsuccessful and they had amputation of the lower limb.

Conclusion. Performing carotid endarterectomy in combination with surgical treatment of distant complications of revascularization of the aorto-femoral arterial segment made it possible to prevent the development of neurological complications and achieve good results in $94.1 \%$. in the surgical treatment of the combined atherosclerotic lesions of ICA and remote complications reconstruction of atherosclerotic operations occlusion of the aorto-iliac-femoral arterial zone.

Key words: obliterating atherosclerosis; arterial reconstruction; carotid endarterectomy; revascularization.

цієнтів розвинувся пізній тромбоз однієї із бранш аорто-клубово-бісеморального алопротеза, у 6 (4,26 \%) пацієнтів діагностовано несправжню аневризму дистального анастомозу біфеморального алошунта, у 4 (2,84 \%) - пізні інсрекційні ускладнення у вигляді нориці ділянки дистального анастомозу, в $83(58,87 \%)$ встановлено рецидив хронічної артеріальної недостатності нижніх кінцівок (XАН II Б та ХАН III А ст. (за класисрікацією R. Fontaine з урахуванням критеріїв Європейської робочої групи (1992)).

Серед 148 пацієнтів із пізніми ускладненнями хірургічного лікування аорто-клубово-стегнового артеріального басейну в 132 (89,19 \%) виявлено атеросклеротичне ураження внутрішньої сонної артерії (BCA). 3 них у $47(35,61 \%)$ спостереженнях стенотичний процес ВСА знаходився у межах 18-34 \%, у 85 (64,39 \%) пацієнтів він був на рівні 57 \% і вище.

Характер атеросклеротичного ураження, ступінь стено-оклюзивного процесу і стан церебральної гемодинаміки визначали за допомогою ультрасонограсра «Siemens Acuson S2000».

Ультразвукову доплерограсрію артеріального русла нижніх кінцівок здійснювали апаратом «Ultima PA» Україна (Радмір), використовуючи лінійний датчик з частотою 7 Мгц та конвексний датчик 3 частотою 3,5 Мгц.

Магнітно-резонансну томографію головного мозку виконували за допомогою 1,5 Tesla Excelart Vantage Toshiba Medtcal System.

Для діагностики оклюзійно-стенотичних уражень аорти та магістральних артерій нижніх кінцівок та артерій головного мозку застосовували комп'ютерну томографрію із ангіопідсиленням на апараті Philips Brilliance 64.

\section{РЕЗУЛЬТАТИ Й ОБГОВОРЕННЯ}

Хірургічні втручання у пацієнтів з ураженням ВСА виконували згідно з додатком до наказу МОЗ України № 317 від 13.06.2008 «Клінічний протокол 
надання нейрохірургічної допомоги хворим із наслідками ішемічного інсульту при оклюзіях і стенозах прецеребральних та мозкових артерій», що узгоджується з Керівництвом щодо ведення пацієнтів із захворюваннями екстракраніальних відділів сонних та вертебральних артерій», затверджене Американською спілкою ангіологів, 2011 [8] та «нвазивне лікування стенозу сонних артерій: показання, техніка», прийнятою Європейським товариством судинних хірургів, 2009 [9].

У дослідження увійшло 85 пацієнтів із пізніми ускладненнями реконструкції аорто-клубово-стегнового артеріального басейну, в яких стенозуючий процес ВСА знаходився на рівні 50 \% і вище. В групу включено двох хворих, у яких після реваскуляризаційного втручання на аорто-клубово-стегновій зоні через 1,7 і 2,0 роки після операції мало місце гостре порушення мозкового кровообігу. Необхідно відмітити, що стеноз ВСА на рівні $72 \%$ виявлений в одному спостереженні й на рівні 93 \% - в іншому. Серед вказаної кількості обстежених у 54 (62,07 \%) пацієнтів зустрічався стеноз ВСА на рівні 70-89 \%, стеноз на рівні 50-69 \% - у 31 хворого. У 2 (2,29\%) спостереженнях стеноз ВСА був на рівні 90-99\%.

Встановлено, що в усіх пацієнтів одночасно мало місце стенозування контрлатеральної ВСА. Так, у 72 (82,75 \%) спостереженнях зустрічався стеноз контрлатеральної ВСА на рівні $<50 \%$, у 9 $(10,35 \%)$ випадках - на рівні 50-69 \%, у - 5 (5,74 \%) - на рівні 70-89 \%, а у 1 - на рівні 90-99 \%.

Стенозуючий процес ВСА сприяє розвитку порушення мозкового кровообігу. Для оцінки тяжкості порушення мозкового кровообігу використали Марсельську класифікацію (1986 р.). Згідно з нею у пацієнтів із атеросклеротичним ураженням екстракраніальних артерій найчастіше виявляли безсимптомне ураження - у 61 (70,12 \%) спостереженні, транзиторну ішемічну атаку (amaurosis fugax) - у 17 $(20,99 \%)$ осіб. Набагато рідше було діагностовано інсульт доконаний - у 2 (2,30 \%) хворих.

При хірургічній корекції кровообігу по ВСА виконали 43 (49,43 \%) класичних КE, 23 (26,44 \%) ретроградних КЕ, 11 (12,64 \%) - еверсійних КЕ. У 8 спостереженнях (9,19 \%) здійснене стентування ВСА (табл. 1).

При ультрасонографрічному дуплексному дослідженні пікова систолічна швидкість кровообігу (ПСШК) по середній мозковій артерії (СМА) у практично здорових осіб знаходиться в межах 73$129 \mathrm{~cm} / \mathrm{c}$. У пацієнтів із атеросклеротичним стенозом ВСА до хірургічної його корекції ПСШК по СМА була значно нижчою (табл. 2), у більшості пацієнтів вона утримувалась на рівні 30-59 см/с. А у 7 (9,19 \%) хворих ПСШК по СМА була в межах 60-69 см/с.

Після хірургічної корекції кровообігу по ВСА ПСШК по СМА істотно зросла. У 46 (52,87 \%) пацієнтів ПСШ реєструвалась на рівні 70-79 cм/с, у
Таблиця 1. Каротидна ендартеректомія у пацієнтів із ураженням внутрішньої сонної артерії

\begin{tabular}{l|c}
\hline $\begin{array}{c}\text { Спосіб каротидної } \\
\text { ендартеректомії }\end{array}$ & Кількість \\
\hline Класична & $43(49,43 \%)$ \\
\hline Ретроградна & $23(26,44 \%)$ \\
\hline Еверсійна & $11(12,64 \%)$ \\
\hline Стентування & $8(9,19 \%)$ \\
\hline Усього & 87 \\
\hline
\end{tabular}

Таблиця 2. Пікова систолічна швидкість кровообігу по середній мозковій артерії у пацієнтів з ураженням внутрішньої сонної артерії до і після каротидних ендартеректомій

\begin{tabular}{c|c|c}
\hline $\begin{array}{c}\text { Пікова систолічна } \\
\text { швидкість крово- по середній } \\
\text { мозковій артерії, } \\
\text { см/с }\end{array}$ & $\begin{array}{c}\text { До хірургічного } \\
\text { лікування, } \\
\text { кількість хворих }\end{array}$ & $\begin{array}{c}\text { Після хірургічного } \\
\text { лікування, } \\
\text { кількість хворих }\end{array}$ \\
\hline $30-39$ & $20(22,99 \%)$ & \\
\hline $40-49$ & $39(45,63 \%)$ & \\
\hline $50-59$ & $21(24,14 \%)$ & $12(13,79 \%)$ \\
\hline $60-69$ & $7(9,19 \%)$ & $46(52,87 \%)$ \\
\hline $70-79$ & & $27(31,03 \%)$ \\
\hline $80-89$ & & $1(1,15 \%)$ \\
\hline $90-99$ & & 87 \\
\hline $110-119$ & &
\end{tabular}

27 (31,03 \%) - на рівні 80-89 см/с і тільки в одного - на рівні 90-99 cm/c.

Підвищення ПСШК по СМА після КЕ ВСА підтверджує ефрективність хірургічного лікування атеросклеротичного стенозу ВСА. Але раптове зростання ПСШК по СМА може бути причиною розвитку церебральної гіперперфузії (ЦГ). У двох пацієнтів після завершення хірургічного втручання виявили симптоми ЦГ. Остання проявлялась у вигляді іпсилатерального головного болю, нудотою, одноразовою блювотою. Патологію ЦГ оцінено як II ступінь - легкий перебіг ЦГ згідно з класиорікацією І. І. Кобзи [14]. Симптоматика ЦГ, що з'явилась відразу після закінчення операції KE, проявилась у двох пацієнтів, котрі після реваскуляризаційного втручання на аорто-клубово-стегновому сегменті через 1,7 і 2,0 роки перенесли гостре порушення мозкового кровообігу. Хворі для хірургічної корекції стенотично-оклюзивного ураження ВСА були госпіталізовані через 8-11 місяців після перенесеного гострого порушення мозкового кровообігу із діагнозом інсульту доконаного, V ст. порушення мозкового кровообігу (за Марсельською класифрікацією). До проведення КЕ ПСШК по СМА у них була в межaх 40-49 см/c, а після оперативного втручання досягла в одному спостереженні рівня 80-89 cм/c, а в іншому - 70-79 cм/c. 
Після КЕ ВСА 85 пацієнтам проведено хірургічне втручання з приводу віддалених ускладнень оперативного лікування аорто-клубово-стегнового артеріального басейну. В 78 (91,76 \%) спостереженнях повторну реконструктивну операцію пізніх ускладнень здійснено одномоментно із КЕ ВСА. У 4 пацієнтів КЕ ВСА проведено на 9-12 добу, в 3 хворих - на 13-16 добу після хірургічного лікування ускладнених фрорм реконструкції атеросклеротичної оклюзії аорто-клубово-стегнового артеріального басейну.

Наступним етапом хірургічного лікування, одномоментно або відстрочено, поєднаної патології ВСА та віддалених ускладнень реваскуляризації аорто-клубово-стегнової зони були оперативні втручання при різних фрормах пізніх ускладнень реконструкції аорто-клубово-стегнового артеріального басейну. Серед останніх були: 21 пацієнт із пізнім тромбозом бранш аорто-клубово-біфреморального алопротеза, одне спостереження із несправжньою аневризмою дистального аорто-біфреморального алошунта та 64 хворих із рецидивом хронічної артеріальної недостатності нижніх кінцівок (ХАН ІІ Б ст., 21 спостереження, ХАН III А ст., 43 спостереження за класифрікацією R. Fontaine з урахуванням критеріїв Європейської робочої групи (1992)).

У ранньому післяопераційному періоді не виявленого жодного випадку розвитку неврологічного ускладнення. Поряд із наведеним діагностовано 8 $(9,41 \%)$ тромбозів реконструйованих сегментів. Шляхом повторних реконструктивних (3 спостереження) операцій та тромбектомії (5 спостережень) із стегнодистального шунта вдалось відновити кровообіг. На 2-4 добу в 3 хворих із групи 3 повторно відновленим кровообігом розвинувся ретромбоз. Повторні хірургічні втручання у 2 спостереженнях не мали успіху й у них була проведена ампутація нижньої кінцівки.

У 3 (3,61 \%) пацієнтів після повторної реваскуляризації нижніх кінцівок відзначили збереження і прогресування ішемії нижніх кінцівок. Інтенсивна консервативна терапія дозволила субкомпенсувати ішемічні прояви в одного пацієнта й обмежитись економною ампутацією на рівні стопи. У двох інших інтенсивні консервативні методи лікування не дозволили компенсувати прогресуючу ішемію, що призвело до виконання ампутації нижніх кінцівок.

Надійним способом, який дозволяє запобігти розвитку ішемічного інсульту у хворих і гемодина-

\section{СПИСОК ЛІТЕРАТУРИ}

1. Anthony Th. Optimal outcome for "high-risk" carotid enarterectomy / Th. Anthony, K. Johansen // Amer. J. Serg. - 2009. - Vol. 167, No. 5. - P. 469-471.

2. Dirnagl U. Preconditioning and tolerance against cerebral ischaemia: from experimental strategies to clinical use / U. Dirnagl, A. Meisel // Lancet Neurol. - 2009. - Vol. 8 (4). - P. 398-412.

3. Guideline on the management of patients with мічно значними ураженнями і симтомами хронічної мозкової недостатності, є КЕ [11-13].

Хірургічну корекцію стенотично-оклюзивного ураження ВСА методом КЕ проведено у 90,8 \% спостереженнях. Ефективність її виконання підтверджено зростанням ПСШК по СМА після закінчення хірургічного втручання на ВСА у середньому в $1,5(p<0,05)$ раза.

У ряді досліджень, присвячених оперативному лікуванні поєднаного атеросклеротичного ураження екстракраніальних судин та аорто-клубовостегнового артеріального басейну, наголошується на необхідності проведення хірургічного лікування стенотично-оклюзивного процесу сонних артерій $[5,10]$. У цьому вбачається прагнення запобігти розвитку неврологічних ускладнень при реваскуляризації поєднаного атеросклеротичного стенотично-оклюзивного процесу судин шиї та аортостегнової зони [8].

У дослідженні після КЕ ВСА 85 пацієнтам проведено хірургічне втручання з приводу віддалених ускладнень оперативного лікування атеросклеротичного ураження аорто-клубово-стегнового артеріального басейну. В 78 (91,76 \%) спостереженнях реконструктивне втручання при пізніх ускладненнях здійснено одномоментно із КЕ ВСА. У 4 пацієнтів КЕ ВСА проведено на 9-12 добу, в 3 хворих - на 13-16 добу після хірургічного лікування ускладнених фрорм реконструкції атеросклеротичної оклюзії аорто-клубово-стегнового артеріального басейну.

При аналізі перебігу раннього післяопераційного періоду не виявленого жодного випадку розвитку неврологічного ускладнення. Одночасно діагностовано 8 (9,41 \%) тромбозів реконструйованих сегментів.

\section{ВИСНОВКИ}

Виконання КЕ в поєднанні із хірургічним лікуванням віддалених ускладнень реваскуляризації атеросклеротичного ураження аорто-клубово-стегнового артеріального басейну дало можливість попередити розвиток неврологічних ускладнень і досягти в 94,1 \% хороших результатів у хірургічному лікуванні поєднаного атеросклеротичного ураження ВСА і віддалених ускладнень реконструктивних операцій атеросклеротичної оклюзії аорто-клубовостегнової артеріальної зони.

extracraenial carotid and vertebral artery disease / T. G. Brott, J. I. Halperin, S. Abbara [et al.] // J. Am. Coll. Cariol. - 2011. - Vol. 57, No. 4. - P. 1002-1044.

4. Hallett J. V. Selection and preparation of high-risk patient for repair of abdominal aortic aneurysm / J. V. Hallett, T. C. Bower, K. J. Cherry // Mayo Clin. Proc. - 2004 Vol. 69, No. 6. - P. 763-768.

5. Selective neutonal damage and Wisconsin Card 
Sorting Test performance in atherosclerotic occlusive disease of the major cerebralartery / H. Yamauchi, R. Nishi, T. Higashi [et al.] // J. Neurol. Neurosurg. Psychiatry. - 2011 - Vol. 82. - P. 150-156.

6. The ESVS Guidelines Collaborators. ESVS Guidelines. Invasive treatment for carotid stenosis: Indications, techniques / C. D. Liapis, P. R. F. Bell, D. Mikhailidis [et al.] // Eur. J. Vasc. Endovasc. Surg. - 2009. - Vol. 37. - P. 1-19.

7. Result of the New York carotid artery surgery study risk factors for perioperative death and stroke after carotid endarterectomy: Result of the New York Carotid Artery Surgery Study / E. A. Halm, S. Tuhrim, J. J. Wang [et al.] // Stroke. - 2009. - Vol. 40. - P. 221-229.

8. Гибридные оперативные вмешательства при многоуровневых поражениях брахиоцефальных артерий у пациентов с сосудистомозговой недостаточностью / А. Ф. Карпенко, В. Б. Стародубцев, А. М. Чернявский [и др.] // Ангиология и сосудистая хирургия. - 2010. - Т. 16, № 4. - С. 130-134.

9. Ковальчук Л. Я. Хірургія поєднаних і множинних атеросклеротичних оклюзій екстракраніальних артерій та аорто-стегнового сегменту / Л. Я. Ковальчук, І. К. Венгер, С. Я. Костів. - Тернопіль : ТДМУ, 2005. - С. 198.

\section{REFERENCES}

1. Anthony Th, Johansen K. Optimal outcome for "highrisk" carotid endarterectomy. Amer J Serg. 2009;167(5): 469-71.

2. Dirnagl U, Meisel A. Preconditioning and tolerance against cerebral ischaemia: from experimental strategies to clinical use. Lancet Neurol. 2009; 8 (4): 398-412.

3. Brott TG, Halperin JI, Abbara SA. Guideline on the Management of patients with extracraenial carotid and vertebral artery disease. J Am Coll Cariol. 2011;57(4): 1002-44.

4. Hallett JV, Bower TC, Cherry KJ. Selection and preparation of high-risk patient for repair of abdominal aortic aneurysm. Mayo Clin Proc. 2004;69(6): 763-8.

5. Yamauchi $H$, Nishi R, Higashi T. Selective neutonal damage and Wisconsin Card Sorting Test performance in atherosclerotic occlusive disease of the major cerebralartery. Neurol Neurosurg Psychiatry. 201.82: 150-6.

6. Liapis CD, Bell PRF, Mikhailidis D. The ESVS Guidelines Collaborators. ESVS Guidelines. Invasive Treatment for Carotid Stenosis: Indications, Technigues Vasc Endovasc Surg. 2009.37: 1-19.

7. Halm EA, Tuhrim S, Wang JJ. Result of the New York carotid artery surgery study risk factors for perioperative death and stroke after carotid endarterectomy: Result of the New York Carotid Artery Surgery Study. Stroke. 2009;40: 221-9.
10. Тактика лечения мультифокального атеросклероза / П. И. Никульников, А. В. Ратушняк, С. Н. Фуркало [и др.] // Вісник Української медичної стоматологічної академії. - 2015. - Т. 9, № 1. - С. 318-321.

11. Мазур С. Г. Вікові особливості стану сонних артерій та церебральної гемодинаміки у хворих, що перенесли ішемічний інсульт, залежно від півкульової локалізації вогнища / С. Г. Мазур // Нейрорадіологія. - 2012. № 4. - С. 5-16.

12. Лаврентьев А. В. Специализированый инструмент для эверсионной каротидной эндартерэктомии / А. В. Лаврентьев, О. В. Виноградов, А. Н. Щербюк // Ангиология и сосудистая хирургия. - 2011. - Т. 17, № 3. С. $131-140$.

13. Серцево-судинні і серцево-мозкові захворювання. Регіональні шляхи оптимізації медичної допомоги / І. Л. Ревенко, В. А. Гандзюк ; за ред. проф. В. М. Корнацького. - К., 2012. - 191с.

14. Трутяк Р. І. Церебральна гіперперсузія в хірургії сонних артерій : автореф. дис. на здобуття наук. ступ. канд. мед. наук : 1401 03. Тернопільський державний медичний університет імені І. Я. Горбачевського МОЗ України. - Тернопіль, 2014. - 20 с.

8. Karpenko AF, Starodubtsev AF, Chernyavskiy AM. [Hybrid surgical interventions for multilevel lesions of the brachiocephalic arteries in patients with cerebrovascular insufficiency]. Angiologiya i sosudistaya khirurgiya. 2010;16(4): 130-4. Russian.

9. Kovalchuk LYa. Surgery of combined and multiple atherosclerotic occlusions of extracranial arteries and aortofemoral segment. [Хірургія поєднаних і множинних атероа склеротичних оклюзій екстракраніальних артерій та аоре то-стегнового сегменту] Ternopil: TDMU "Ukrmedknyha"; 2005. Ukrainian.

10. Nikulnikov PI, RatushnyakAV, Furkalo SN, Guch AA, Liksunov AV. [Treatment tactics for multifocal atherosclerosis]. Visnyk Ukrainskoi medychnoi stomatolohichnoi akademii. 2015;9(1): 318-21. Russian.

11. Mazur SG. [Age features of the condition of the carotid arteries and cerebral hemodynamics in patients with ischemic stroke, depending on the hemispherical location of the focus]. Neuroradiologia.2012;4: 5-16. Ukrainian

13. Kornatskiy VM, Rovenko IL, Gandzuk VF. Regional ways to optimize health care. [Серцево-судинні і серцевомозкові захворювання. Регіональні шляхи оптимізації медичної допомоги] Kyiv; 2012. Ukrainian.

14. Trutyak RI [Cerebral hyperperfusion in carotid artery surgery] [dissertation]. I. Horbachevsky Ternopil State Medical University. Ternopil; 2014. Ukrainian. 